\title{
The Use of Activities of Carbon Catabolic Enzymes as a Probe for the Carbon Nutrition of Snakebean Nodule Bacteroids
}

\author{
By S. SAROSO, M. J. DILWORTH AND A. R. GLENN* \\ Nitrogen Fixation Research Group, School of Environmental and Life Sciences, \\ Murdoch University, Murdoch, Western Australia
}

(Received 3 July 1985)

In sugar-grown cells of cowpea Rhizobium strain NGR234 activities for enzymes of the EntnerDoudoroff and pentose phosphate pathways were present while the virtual absence of phosphofructokinase and fructose-bisphosphate aldolase indicated that the Embden-Meyerhof-Parnas pathway was unlikely to be significant. Invertase, fructokinase, glucose-6-phosphate dehydrogenase and the Entner-Doudoroff enzymes were present at only low activities in succinate grown cells, but were induced in sugar-grown cells. Isolated snakebean bacteroids contained very low activities of these four enzymes. Although $\mathrm{C}_{4}$-dicarboxylic acids exerted some repressive effect on induction of these enzymes, there was substantial enzyme activity induced in cells grown on sucrose plus a $\mathrm{C}_{4}$ dicarboxylic acid. The data suggest that the peribacteroid membrane may be relatively impermeable to sugars and so dictate the carbon source(s) available to the bacteroids.

\section{INTRODUCTION}

The carbon metabolism of rhizobial bacteroids in legume root nodules has been a subject of interest for some time. A number of approaches have been used to probe the nature of the carbon compounds which are used by bacteroids for their development and to fuel the energy intensive process of $\mathrm{N}_{2}$-fixation. In particular, studies have focused on the use of mutants defective in the ability to utilize particular carbon compounds (Ronson \& Primrose, 1979; Ronson et al., 1981; Glenn et al., 1984; Arwas et al., 1985) and on the uptake of metabolites (Dilworth \& Glenn, 1984). Studies of various mutants of Rhizobium trifolii (Ronson \& Primrose, 1979; Ronson et al., 1981) and Rhizobium leguminosarum (Glenn \& Brewin, 1981; Finan et al., 1983; Glenn et al., 1984; Arwas et al., 1985) have shown that sugar-defective mutants nodulate and fix $\mathrm{N}_{2}$ whereas dicarboxylate transport mutants nodulate but are ineffective. These data suggest that the ability to utilize $\mathrm{C}_{4}$-dicarboxylic acids is crucial to an effective symbiosis, whereas the capacity to metabolize sugars is not essential. Most studies which have examined uptake of carbon compounds in isolated bacteroids have reported that they do not actively accumulate sugars (Dilworth \& Glenn, 1984), but may receive small amounts by passive diffusion (Reibach \& Streeter, 1984). Because of the possibility of the loss of binding proteins or some other surface components essential for transport (Dilworth \& Glenn, 1981), transport studies with bacteroids without additional supporting data should, we believe, be regarded with some caution. For this reason we have sought an alternative biochemical index of the physiological status of the bacteroid in legume root nodules.

During the course of work on substrate-dependent $\mathrm{O}_{2}$ consumption of cowpea Rhizobium strain NGR234 (Saroso et al., 1984) we found that this organism had a large number of inducible catabolic enzyme systems. Some of these enzymes, particularly those associated with catabolism of sucrose, glucose and fructose, have now been investigated in more detail with a view to using

Abbreviation: PEPCK, phosphoenolpyruvate carboxykinase. 
their activities as a way of investigating the physiological status of snakebean bacteroids of strain NGR234.

\section{METHODS}

Organism. Cowpea Rhizobium NGR234 was obtained from Dr M. Trinick, CSIRO, Perth, Western Australia. This strain is a typical fast-grower (Broughton \& Dilworth, 1971) but nodulates both cowpea (Vigna unguiculata (L.) Walp. subsp. unguiculata) and snakebean (V. unguiculata subsp. sesquipedalis (L.) Verdc.).

Media. Bacteria were grown at $28^{\circ} \mathrm{C}$ in batch culture in the minimal salts medium of Brown \& Dilworth (1975) with carbon source at $10 \mathrm{mM}, \mathrm{NH}_{4}^{+}$at $10 \mathrm{~mm}$ as nitrogen source and phosphate at $0.3 \mathrm{mM}$. HEPES buffer ( $40 \mathrm{mM}$, $\mathrm{pH} 7 \cdot 0$ ) was added to maintain the $\mathrm{pH}$.

Nodulation and preparation of bacteroids. Snake bean seeds (dwarf variety), obtained from Arthur Yates \& Co., Perth, Western Australia, were surface sterilized with $\mathrm{HgCl}_{2}(0.2 \%)$ (Vincent, 1970) and inoculated with strain NGR234. Sixty days after inoculation bacteroids were isolated by either differential centrifugation as described by Glenn et al. (1980) or by a modification of the Percoll gradient method of Reibach et al. (1981) as described by McKay et al. (1985).

Analytical methods. Protein was measured by the Lowry method using bovine serum albumin as a standard.

Enzyme assays. Cell-free extracts were prepared as described by Glenn et al. (1984). Invertase (EC 3.2.1.26) was assayed using the method of Trinder (1969), except that the buffer was $50 \mathrm{~mm}$-HEPES, pH 7.5. Sucrose phosphorylase (EC 2.4.1.7) was assayed using a method modified from Mieyal (1972) with 25 mM-phosphate

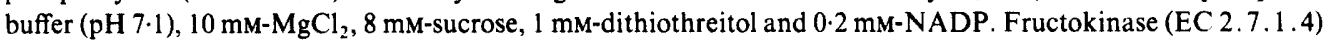
was measured with the glucokinase assay system of Lynch et al. (1975) with fructose as substrate and $50 \mathrm{mM}-$ HEPES (pH 7.0) as the buffer. Glucokinase (EC 2.7.1.2), glucose-6-phosphate isomerase (EC 5.3.1.9), triosephosphate isomerase (EC 5.3.1.1), fructose-1,6-bisphosphatase (EC 3.1.3.11), glucose-6-phosphate dehydrogenase (EC 1.1.1.49), 6-phosphogluconate dehydrogenase (EC 1.1.1.44) and phosphofructokinase (EC 2.7.1 .11) were assayed using the methods outlined by Lynch et al. (1975). Fructose-1,6-bisphosphate aldolase (EC 4.1.2.13) was assayed by the methods of Lynch et al. (1975) and Stowers \& Elkan (1983). The Entner-Doudoroff enzymes (6-phosphogluconate dehydratase, EC 4.2.1.12 and 2-keto-3-deoxy-6-phosphogluconate aldolase, EC 4.1.2.14) were measured using the method of Keele et al. (1969).

Glyceraldehyde-3-phosphate dehydrogenase (EC 1.2.1.12) was measured by the method of Allison \& Kaplan (1964). Phosphoglycerate kinase (EC 2.7.2.3) was determined using the method of Suzuki \& Imahori (1982), and phosphoglyceromutase (EC 5.4.2.1) and enolase (EC 4.2.1.11) by the method of Mulongoy \& Elkan (1977). The pyruvate kinase (EC 2.7.1.40) assay was modified from that of Bucher \& Pfleiderer (1955), using $50 \mathrm{mm-}$ phosphate buffer (pH 7.5), $2 \mathrm{~mm}-\mathrm{ADP}, 0.2 \mathrm{~mm}-\mathrm{NADH}, 10 \mathrm{mM}-\mathrm{MgCl}_{2}$ and $5 \mathrm{~mm}$-phosphoenolpyruvate.

Ribose-5-phosphate isomerase (EC 5.3.1.6), ribulose-5-phosphate epimerase (EC 5.1.3.1) and transaldolase (EC 2.2.1.2) were measured using the methods of Novello \& McLean (1968). Transketolase (EC 2.2.1.1) was assayed by the method of Stowers \& Elkan (1983).

3-Hydroxybutyrate dehydrogenase (EC 1.1.1.30) was assayed using $100 \mathrm{~mm}$-Tris/ $\mathrm{HCl}$ buffer (pH 8.0), 0.5 mM$\mathrm{NAD}^{+}, 26 \mathrm{mM}-3$-hydroxybutyrate, $10 \mathrm{mM}-\mathrm{MgCl}_{2}$ and $10 \mathrm{~mm}$-potassium cyanide. Phosphoenolpyruvate carboxylase (EC 4.1.1 .31) was assayed as described by Reibach \& Benedict (1977). Phosphoenolpyruvate carboxykinase (PEPCK, EC 4.1 1.1.49) was assayed according to the method of Krebs \& Bridger (1980) except that the buffer was 70 mM-imidazole (pH 6.8).

The method of Reeves et al. (1971) was used to assay citrate synthase (EC 4.1.3.7). Aconitase (EC 4.2.1.3) was measured by coupling to commercial isocitrate dehydrogenase (5 units) (Ochoa, 1955) except the buffer was $35 \mathrm{~mm}-\mathrm{HEPES}$ ( $\mathrm{pH} 7$ ), and trisodium citrate was at $10 \mathrm{mM}$. The rhizobial enzyme had an absolute requirement for cysteine $(0.5 \mathrm{~mm})$ and $\mathrm{FeSO}_{4}(0.5 \mathrm{mM})$. 2-Oxoglutarate dehydrogenase (EC 1.2.4.2) was measured by the method of Von Tigerstrom \& Campbell (1966), succinic thiokinase (EC 6.2.1.5) as described by Cha (1969), and succinate dehydrogenase (EC 1.3.99.1) as described by Hederstadt et al. (1979) except that the buffer was 12 mMpotassium phosphate $(\mathrm{pH} \mathrm{7.4)}$ and the substrate was $10 \mathrm{mM}$ succinate. Fumarase (EC 4.2.1.2) was assayed by the method of Hill \& Bradshaw (1969) except the buffer was $80 \mathrm{~mm}$-potassium phosphate (pH 8) and malate was at $10 \mathrm{mM}$. Malate dehydrogenase (EC 1.1.1.37) was assayed using $60 \mathrm{~mm}$-potassium phosphate (pH 7.5), $0 \cdot 2 \mathrm{mM}$ $\mathrm{NADH}, 2 \mathrm{mM}$-oxaloacetate and $1 \mathrm{mM}-\mathrm{KCN}$. Isocitrate dehydrogenase (EC 1.1.1.41) was measured using $35 \mathrm{~mm}-$ HEPES (pH 7.8), $1 \mathrm{~mm}-\mathrm{MnSO}_{4}, 1 \mathrm{mM} \mathrm{MgSO}_{4}, 0.2 \mathrm{~mm}$-NADP and $10 \mathrm{~mm}$-DL-trisodium isocitrate.

Enzymes were from Sigma and chemicals from $\mathrm{BDH}$ or Ajax Chemicals.

\section{RESULTS AND DISCUSSION}

\section{Pathways of sugar catabolism}

Cell-free extracts derived from glucose grown cells of strain NGR234 contained enzymes of the Entner-Doudoroff pathway (Table 1). The enzymes of the pentose phosphate pathway (6- 
Table 1. Activities of sugar catabolic enzymes in free-living cells and snakebean bacteroids of cowpea Rhizobium NGR234

These data are derived from at least three separate measurements.

Activity [nmol $\left.\min ^{-1}(\mathrm{mg} \text { protein })^{-1}\right]$

\begin{tabular}{|c|c|c|c|c|c|}
\hline Enzyme & Glucose & Fructose & Sucrose & Succinate & Bacteroids \\
\hline Invertase & $2 \pm 0$ & $1 \pm 0$ & $26 \pm 3$ & $2 \pm 1$ & $1 \pm 1$ \\
\hline Fructokinase & $16 \pm 3$ & $54 \pm 5$ & $29 \pm 1$ & $14 \pm 2$ & 0 \\
\hline $\begin{array}{l}\text { Glucose-6-phosphate } \\
\text { isomerase }\end{array}$ & $213 \pm 1$ & $196 \pm 7$ & $245 \pm 6$ & $103 \pm 23$ & $187 \pm 2$ \\
\hline Glucokinase & $54 \pm 5$ & $50 \pm 9$ & $57 \pm 5$ & $27 \pm 4$ & $16 \pm 1$ \\
\hline $\begin{array}{l}\text { Glucose-6-phosphate } \\
\text { dehydrogenase }\end{array}$ & $118 \pm 16$ & $61 \pm 16$ & $60 \pm 3$ & $9 \pm 3$ & $7 \pm 2$ \\
\hline Entner-Doudoroff enzymes & $155 \pm 40$ & $137 \pm 10$ & $137 \pm 25$ & $8 \pm 1$ & $7 \pm 1$ \\
\hline Phosphofructokinase & $\overline{0}$ & $2 \pm 1$ & $2 \pm 1$ & $3 \pm 1$ & $3 \pm 0$ \\
\hline $\begin{array}{l}\text { Fructose-1,6-bisphosphate } \\
\text { aldolase }\end{array}$ & $3 \pm 0$ & $5 \pm 1$ & $7 \pm 1$ & $16 \pm 1$ & $13 \pm 3$ \\
\hline Triosephosphate isomerase & $122 \pm 16$ & $204 \pm 20$ & $121 \pm 5$ & $222 \pm 29$ & $100 \pm 12$ \\
\hline $\begin{array}{l}\text { Glyceraldehyde-3-phosphate } \\
\text { dehydrogenase }\end{array}$ & $18 \pm 3$ & $11 \pm 1$ & $10 \pm 2$ & $15 \pm 3$ & $15 \pm 0$ \\
\hline Phosphoglycerate kinase & $134 \pm 15$ & $173 \pm 2$ & $125 \pm 3$ & $126 \pm 5$ & $31 \pm 4$ \\
\hline Phosphoglyceromutase & $15 \pm 3$ & $13 \pm 2$ & $7 \pm 2$ & $12 \pm 3$ & $14 \pm 3$ \\
\hline Enolase & $52 \pm 8$ & $56 \pm 7$ & $117 \pm 1$ & $73 \pm 12$ & $44 \pm 5$ \\
\hline Pyruvate kinase & $46 \pm 1$ & $75 \pm 9$ & $85 \pm 10$ & $149 \pm 14$ & $130 \pm 1$ \\
\hline $\begin{array}{l}\text { 6-Phosphogluconate } \\
\text { dehydrogenase }\end{array}$ & $31 \pm 1$ & $27 \pm 2$ & $30 \pm 7$ & $12 \pm 4$ & $9 \pm 2$ \\
\hline $\begin{array}{l}\text { Ribose-5-phosphate } \\
\text { isomerase }\end{array}$ & $56 \pm 4$ & $43 \pm 3$ & $42 \pm 2$ & $26 \pm 4$ & $16 \pm 4$ \\
\hline $\begin{array}{l}\text { Ribulose-5-phosphate } \\
\text { epimerase }\end{array}$ & $97 \pm 4$ & $77 \pm 3$ & $79 \pm 7$ & $32 \pm 2$ & $27 \pm 1$ \\
\hline Transketolase & $24 \pm 3$ & $15 \pm 1$ & $22 \pm 7$ & $12 \pm 4$ & $17 \pm 1$ \\
\hline Transaldolase & $48 \pm 7$ & $41 \pm 7$ & $30 \pm 3$ & $14 \pm 5$ & $6 \pm 2$ \\
\hline
\end{tabular}

phosphogluconate dehydrogenase, ribose-5-phosphate isomerase, ribulose-5-phosphate epimerase, transketolase and transaldolase) were also present (Table 1). Phosphofructokinase, a key enzyme in the Embden-Meyerhof-Parnas (EMP) pathway, was present in barely detectable levels even though it was assayed $(a)$ over the pH range 6-7.5 (in 50 mM-MES or HEPES or $40 \mathrm{mMTris} / \mathrm{HCl}),(b)$ over a fructose 6 -phosphate concentration range of $1-4 \mathrm{mM}$ at an ATP concentration of $2.5 \mathrm{mM},(c)$ over an ATP concentration range of $0.6-4.2 \mathrm{mM}$ at a fructose 6phosphate concentration of $1 \mathrm{mM}$ and $(d)$ in the presence or absence of $1 \mathrm{~mm}$-dithiothreitol. Similarly there was a barely detectable activity of fructose-1,6-bisphosphate aldolase (Table 1) measured in the presence of either $\mathrm{Co}^{2+}$ or $\mathrm{Mg}^{2+}$. The remaining enzymes of the EMP pathway were all present in extracts derived from glucose-grown cells although the activities of glyceraldehyde-3-phosphate dehydrogenase and phosphoglyceromutase were somewhat lower than the others (Table 1). The lack of significant phosphofructokinase and fructose-1,6bisphosphate aldolase in NGR234 suggests that the EMP pathway is probably not a significant route for sugar catabolism in this strain. Similar activities of these sugar catabolic enzymes were observed in cells of NGR234 grown on sucrose or fructose (Table 1). These data suggest that $\mathrm{C}_{6}$ and $\mathrm{C}_{12}$-sugars are metabolized via the Entner-Doudoroff and pentose phosphate pathways and that the EMP pathway is not significant in hexose catabolism. This is similar to the situation described for other fast-growing rhizobia like $R$. trifolii (Ronson \& Primrose, 1979) and $R$. leguminosarum (Glenn et al., 1984).

\section{Inducible sugar catabolic enzymes}

Although sugar grown cells of NGR234 contained significant activities of the enzymes of the Entner-Doudoroff and pentose phosphate pathways, cells grown on a $\mathrm{C}_{4}$-dicarboxylic acid like succinate had only low activities of some of the sugar catabolic enzymes (Table 1). 
Glucose-6-phosphate isomerase was found in cells grown on all carbon sources tested (Table 1), though its activity was significantly lower $(P<0.01)$ in cells grown on succinate than in those grown on sugars. A number of enzymes had significantly lower activities in succinate-grown than in sugar-grown cells, e.g. glucokinase $(P<0.001)$, 6-phosphogluconate dehydrogenase $(P<0.01)$, ribose-5-phosphate isomerase $(P<0.01)$, ribulose-5-phosphate epimerase $(P<0.001)$ and transaldolase $(P<0.05)$. The activities of transketolase, however, were not significantly different (Table 1 ).

By contrast, PEPCK and fructose-1,6-bisphosphate aldolase were significantly $(P<0.001)$ higher in extracts derived from succinate-grown cells than those grown on sugars. These results are consistent with a role for these enzymes in gluconeogenesis. However, these activities were significantly lower than those found for these enzymes in $R$. leguminosarum (McKay et al., 1985).

Invertase was increased $(P<0.001)$ by growth in the presence of sucrose (Table 1) confirming previous work (Glenn \& Dilworth, 1981). Growth in the presence of glucose, fructose, mannitol (Glenn \& Dilworth, 1981) or succinate failed to induce the enzyme. There was no detectable sucrose phosphorylase activity in cell-free extracts of sucrose-grown NGR234, suggesting that invertase is the sole means for the cleavage of sucrose. Fructokinase activity was markedly increased by growth with fructose $(P<0.02)$ and sucrose $(P<0.02)$. Glucose-6-phosphate dehydrogenase $(P<0.01)$ and the Entner-Doudoroffenzymes $(P<0.001)$ were also increased by growth on sugars and were present in only low activities in succinate grown cells (Table 1).

\section{Effect of succinate on the induction of glucose-6-phosphate dehydrogenase and the Entner-Doudoroff enzymes}

Invertase, fructokinase, glucose-6-phosphate dehydrogenase and the Entner-Doudoroff enzymes are of interest because they are induced by growth on particular sugars, and are present in only small amounts in succinate-grown cells. The induction of these enzymes by sugars opens a means of determining whether these sugars are accessible to snakebean bacteroids.

This proposition is valid only if expression of the sugar catabolic enzyme genes is not subject to extreme catabolite repression. Ucker \& Signer (1978) have reported such a cataboliterepression-like phenomenon in $R$. meliloti with succinate preventing the induction of $\beta$ galactosidase. Since $\mathrm{C}_{4}$-dicarboxylic acids like succinate are known to enter snakebean bacteroids (Saroso et al., 1984) and have been shown to be important for $\mathrm{N}_{2}$-fixation in other rhizobia (Ronson et al., 1981; Finan et al., 1983; Arwas et al., 1985) we have checked for possible catabolite repression of sugar catabolic enzymes by succinate.

Cells of NGR234 were grown in fumarate $(10 \mathrm{mM})$ - minimal salts medium to midexponential phase $\left(\mathrm{OD}_{600}^{1 \mathrm{~cm}}\right.$, approx. 0.6), centrifuged, washed twice with salts (Brown \& Dilworth, 1975) and resuspended in fumarate $(10 \mathrm{mM})$ or sucrose $(10 \mathrm{mM})$ or fumarate plus sucrose (both at $10 \mathrm{~mm}$ ). Samples $(50 \mathrm{ml})$ were taken at $2 \mathrm{~h}$ intervals for the preparation of cellfree extracts and the activities of glucose-6-phosphate dehydrogenase and the EntnerDoudoroff enzymes were determined (Fig. 1). There was a 6-fold increase in specific activity of the glucose-6-phosphate dehydrogenase and a 10-fold increase in the activity of the EntnerDoudoroff enzymes in the cells grown on sucrose. In the cells grown on fumarate there was no increase in specific activity. Cells grown on sucrose plus fumarate induced these enzymes to approximately $50 \%$ of the activity found in the sucrose grown cells (Fig. 1). While the $\mathrm{C}_{4}-$ dicarboxylic acid does exert some repressive effect on the induction of these two sugar catabolic enzymes, it does not, even in an equimolar mixture with sucrose, more than partially repress their synthesis.

\section{Enzymes of the tricarboxylic acid (TCA) cycle}

The enzymes of the TCA cycle were essentially constitutive (Table 2) and did not offer any clear-cut variation in activity of value for probing the physiological status of the bacteroid.

\section{Enzyme activities in isolated snakebean bacteroids}

All of the TCA cycle enzymes were present in the bacteroids (Table 2), though some of the activities were significantly lower than those found in free-living cells. The very low activity of PEPCK (Table 2) suggests that snakebean bacteroids are not gluconeogenic and that the plant 


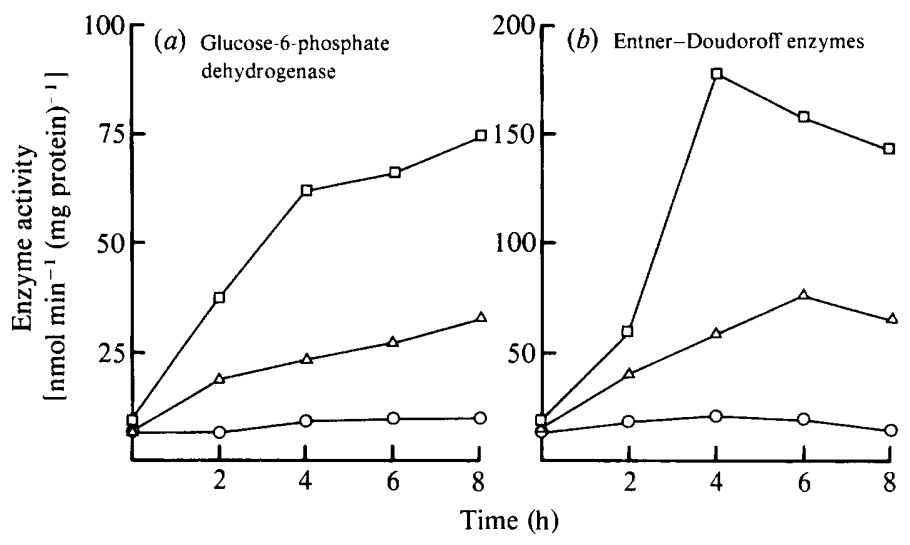

Fig. 1. Induction of glucose-6-phosphate dehydrogenase $(a)$ and Entner-Doudoroff enzymes $(b)$ in Rhizobium NGR234. Cells were grown in fumarate (10 mM)-minimal salt, to mid-exponential phase, harvested by centrifugation, washed twice and resuspended in fumarate $(O)$ or sucrose $(\square)$ or fumarate plus sucrose $(\triangle)$. At $2 \mathrm{~h}$ intervals samples were taken, cell-free extracts prepared and enzyme activity measured.

Table 2. Activities of TCA cycle enzymes, PEPCK and fructose-1,6-bisphosphatase in free-living cells and snake bean bacteroids of cowpea Rhizobium NGR234

These data are derived from at least three separate measurements.

Activity [nmol $\left.\mathrm{min}^{-1}(\mathrm{mg} \text { protein })^{-1}\right]$

Enzyme

Citrate synthase

Aconitase

Isocitrate dehydrogenase

Oxoglutarate

dehydrogenase

Succinic thiokinase

Succinate

dehydrogenase

Fumarase

Malate dehydrogenase

PEPCK

Fructose 1,6-bisphosphatase

\begin{tabular}{|c|c|c|c|c|}
\hline \multicolumn{5}{|c|}{ Activity $\left[\mathrm{nmol} \min ^{-1}(\mathrm{mg} \text { protein })^{-1}\right]$} \\
\hline \multicolumn{4}{|c|}{ Free living cells grown on: } & \multirow[b]{2}{*}{ Bacteroids } \\
\hline Glucose & Fructose & Sucrose & Succinate & \\
\hline $165 \pm 22$ & $228 \pm 1$ & $177 \pm 19$ & $183 \pm 29$ & $130 \pm 16$ \\
\hline $136 \pm 19$ & $93 \pm 1$ & $165 \pm 36$ & $85 \pm 6$ & $132 \pm 19$ \\
\hline $224 \pm 11$ & $245 \pm 1$ & $196 \pm 12$ & $305 \pm 13$ & $130 \pm 6$ \\
\hline $43 \pm 8$ & $79 \pm 12$ & $44 \pm 8$ & $52 \pm 3$ & $22 \pm 2$ \\
\hline $43 \pm 2$ & $45 \pm 4$ & $59 \pm 12$ & $43 \pm 2$ & $60 \pm 15$ \\
\hline $65 \pm 9$ & $71 \pm 1$ & $65 \pm 8$ & $108 \pm 12$ & $29 \pm 2$ \\
\hline $566 \pm 16$ & $389 \pm 32$ & $377 \pm 20$ & $410 \pm 41$ & $229 \pm 25$ \\
\hline $243 \pm 25$ & $347 \pm 20$ & $330 \pm 36$ & $319 \pm 19$ & $286 \pm 1$ \\
\hline $6 \pm 0$ & $11 \pm 1$ & $4 \pm 1$ & $19 \pm 4$ & $3 \pm 1$ \\
\hline $26 \pm 3$ & $19 \pm 4$ & $24 \pm 1$ & $28 \pm 3$ & $23 \pm 0$ \\
\hline
\end{tabular}

must therefore supply sufficient sugar for bacteroid growth and development. A similar situation appears to exist in a PEPCK-deficient mutant of $R$. leguminosarum (McKay et al., 1985).

The activities of the EMP and pentose phosphate enzymes in isolated bacteroids were, on the whole, similar to the activities found in succinate-grown cells. A notable exception to this generalization was phosphoglycerate kinase, which was present in significantly lower activities $(P<0.001)$ in the bacteroid than in free-living cells (Table 1). The lack of phosphofructokinase suggests that the EMP pathway is also inoperative in bacteroids (Table 1).

Snakebean bacteroid extracts contained only low or zero activities of invertase, glucose-6phosphate dehydrogenase, the Entner-Doudoroff enzymes and fructokinase (Table 1). It was important to establish that such enzymes were not being lost from bacteroids by leakage. In control experiments, nodule sap which had been filtered through cheese cloth was centrifuged through Percoll gradients. In such experiments all of the 3-hydroxybutyrate dehydrogenase activity (a bacteroid cytoplasmic marker enzyme) was associated with the bacteroid fraction [25-48 $\left.\mathrm{nmol} \mathrm{\textrm {min } ^ { - 1 } ( \mathrm { mg } \text { protein) }}{ }^{-1}\right]$ and all the phosphoenolpyruvate carboxylase activity (a 
plant cytosol marker enzyme) was associated with the soluble plant fraction. Thus, the very low activities of the inducible sugar catabolic enzymes cannot be explained by leakage from the bacteroid.

Catabolite repression of sugar enzyme synthesis by $\mathrm{C}_{4}$-dicarboxylic acids is also an inadequate explanation of these observations, since Fig. 1 shows that in the free-living bacteria fumarate does not exert a sufficiently strong repressive effect.

These experiments, taken together with the lack of sugar transport or oxidation in isolated bacteroids of NGR234 (Saroso et al., 1984), suggest that sugars do not enter the bacteroid in any significant quantities. Even if hexose phosphates were to enter the bacteroid, the virtual absence of glucose-6-phosphate dehydrogenase would mean that the bacteroid would have only very limited access to the pentose phosphate or Entner-Doudoroff pathways for their metabolism.

An alternative, though we believe unlikely, view is that the regulation of the genes coding for the sugar catabolic enzymes in the bacteroid changes so that the enzymes are insensitive to induction by sugars. Other studies (Saroso et al., 1984) have established that the dicarboxylate permease is induced in the bacteroid, showing that such cells do retain the capacity to respond to external inducers. If sufficient sugars were passing through the peribacteroid membrane, it is difficult to see why a similar induction of sugar transport and catabolic enzymes should not occur. We believe that the simplest explanation consistent with the data is that the peribacteroid membrane is relatively impermeable to sugars, and acts as a control on their entry into the peribacteroid space. If this is indeed the case the peribacteroid membrane may have a crucial role in dictating the flow of metabolites both to and from the bacteroid.

This work was supported by the Australian Research Grants Scheme and by the award of a Colombo Plan research studentship to $\mathrm{S}$.S.

\section{REFERENCES}

Allison, W. S. \& Kaplan, N. O. (1964). The comparative enzymology of triosephosphate dehydrogenase. Journal of Biological Chemistry 239, $2140-2152$.

Arwas, R., McKay, I. A., Rowney, F. R. P., Dilworth, M. J. \& GlenN, A. R. (1985). Properties of organic acid utilization mutants of Rhizobium leguminosarum strain 300. Journal of General Microbiology 131, 2059-2066.

Broughton, W. J. \& Dilworth, M. J. (1971). Control of leghaemoglobin synthesis in snake beans. Biochemical Journal 125, 1075-1080.

Brown, C. M. \& Dilworth, M. J. (1975). Ammonia assimilation by Rhizobium cultures and bacteroids. Journal of General Microbiology 86, 39-48.

Bucher, J. \& Pfleiderer, G. (1955). Pyruvate kinase from muscle. Methods in Enzymology 1, 435-440.

CHA, S. (1969). Succinate thiokinase from pig heart. Methods in Enzymology 13, 62-69.

Dilworth, M. J. \& GlenN, A. R. (1981). Control of carbon substrate utilization by rhizobia. In Current Perspectives in Nitrogen Fixation, pp. 244-256. Edited by A. H. Gibson \& W. E. Newton, Canberra, Australia: Australian Academy of Science.

Dilworth, M. J. \& GlenN, A. R. (1984). Transport in Rhizobium and its significance to the legume symbiosis. In Nitrogen Fixation and $\mathrm{CO}_{2}$ Fixation, pp. 53-61. Edited by P. W. Ludden \& J. E. Burris. New York: Elsevier.

Finan, T. M., Wood, J. M. \& Jordan, D. C. (1983). Symbiotic properties of $\mathrm{C}_{+}$-dicarboxylic acid transport mutants of Rhizobium leguminosarum. Journal of Bacteriolog. 154, 1403-1413.
Glenn, A. R. \& Brewin, N. J. (1981). Succinateresistant mutants of Rhizobium leguminosarum. Journal of General Microbiology' 126, 237-241.

Glenn, A. R. \& Dilworth, M. J. (1981). The uptake and hydrolysis of disaccharides by fast- and slowgrowing species of Rhizobium. Archives of Microbiology 129, 233-239.

Glenn, A. R., Poole, P. S. \& Hudman, J. F. (1980). Succinate uptake by free-living and bacteroid forms of Rhizobium leguminosarum. Journal of General Microbiology 119, 267-271.

Glenn, A. R., MCKay, I. A., ARWaS, R. \& DILworth, M. J. (1984). Sugar metabolism and the symbiotic properties of carbohydrate mutants of Rhizobium leguminosarum. Journal of General Microbiology 130, 239-245.

Hederstedt, L., Holmgren, E. \& Rugberg, L. (1979). Characterization of a succinate dehydrogenase complex solubilized from the cytoplasmic membrane of Bacillus subtilis with the nonionic detergent Triton X-100. Journal of Bacteriology 138, 370-376.

Hill, R. L. \& Bradshaw, R. A. (1969). Fumarase. Methods in Enzymology 13, 91-99.

Keele, B. B., Hamilton, P. B. \& Elkan, G. H. (1969). Glucose catabolism in Rhizobium japonicum. Journal of Bacteriology 97, 1184-1191.

KREBS, A. \& BRIDGER, W. A. (1980). The kinetic properties of phosphoenolpyruvate carboxykinase of Escherichia coli. Canadian Journal of Biochemistry $\mathbf{5 8}$, 309-318.

Lynch, W. H., Macleod, J. \& Franklin, M. (1975). Effect of temperature on the activity and synthesis of glucose-catabolizing enzymes in Pseudomonas 
fluorescens. Canadian Journal of Microbiology 21, $1560-1572$.

McKay, I. A., Glenn, A. R. \& Dilworth, M. J. (1985). Gluconeogensis in Rhizobium leguminosarum MNF3841. Journal of General Microbiology 131, 2067-2073.

Mieyal, J. J. (1972). Sucrose phosphorylase from Pseudomonas saccharophila. Methods in Enzymology 28, 935-943.

Mulongoy, K. \& Elkan, G. H. (1977). Glucose catabolism in two derivatives of a Rhizobium japonicum strain differing in nitrogen-fixing efficiency. Journal of Bacteriology 131, 179-187.

Novello, F. \& MCLean, G. (1968). The pentose phosphate pathway of glucose metabolism. Biochemical Journal 107, 775-791.

OсноA, S. (1955). Isocitrate dehydrogenase system (TPN) from pig heart. Methods in Enzymology 1, 699-704.

ReEves, H. C., Rabin, R., Wegener, W. S. \& Ajl, S. J. (1971). Assays of enzymes of the tricarboxylic acid and glyoxylate cycles. Methods in Microbiology 6A, 425. 462.

ReIBACH, P. H. \& BenEDICT, C. R. (1977). Fractionation of stable carbon isotopes by phosphoenolpyruvate carboxylase from $\mathrm{C}_{4}$ plants. Plant Physiology 59 , $564-568$.

Reibach, P. H. \& Streeter, J. G. (1984). Evaluation of active versus passive uptake of metabolites by Rhizobium japonicum bacteroids. Journal of Bacteriology 159, 47-52.

Reibach, P. H., Mask, P. L. \& Streeter, J. G. (1981). A rapid one-step method for the isolation of bacteroids from root nodules of soybean plants, utilizing self-generating Percoll gradients. Canadian Journal of Microbiolog. 27, 491-495.
Ronson, C. W. \& Primrose, S. B. (1979). Carbohydrate metabolism in Rhizobium trifolii: identification and symbiotic properties of mutants. Journal of General Microbiology 112, 77-88.

Ronson, C. W., Lyttleton, P. \& Robertson, J. G. (1981). C $C_{4}$-Dicarboxylate transport mutants of $R h i$ zobium trifolii form ineffective nodules on Trifolium repens. Proceedings of the National Academy of Sciences of the United States of America 78, 4284 4288.

Saroso, S., GlenN, A. R. \& Dilworth, M. J. (1984). Carbon utilization by free-living and bacteroid forms of cowpea Rhizobium strain NGR234. Journal of General Microbiology 130, 1809-1814.

Stowers, M. D. \& Elkan, G. H. (1983). The transport and metabolism of glucose in cowpea rhizobia. Canadian Journal of Microbiology 29, 398-406.

Suzuki, K. \& Imahori, K. (1982). Phosphoglycerate kinase from Bacillus stearothermophilus. Methods in Enzlmology 90, 126-130.

TRINDER, P. (1969). Determination of glucose in blood using glucose oxidase with an alternative oxygen acceptor. Annals of Clinical Biochemistry 6, 24-27.

UCKer, D. S. \& Signer, E. R. (1978). Cataboliterepression-like phenomenon in Rhizobium meliloti. Journal of Bacteriology 136, 1197-1200.

Vincent, J. M. (1970). A Manual for the Practical Study, of the Root Nodule Bacteria. Oxford: Blackwell Scientific Publications.

Von Tigerstrom, M. \& Campbell, J. J. R. (1966). The tricarboxylic acid cycle, the glyoxylate cycle, and the enzymes of glucose oxidation in Pseudomonas aeruginosa. Canadian Journal of Microbiology 12, $1015-$ 1022. 